\title{
Pan Cytokeratin Staining Method
}

National Cancer Institute

\section{Source}

National Cancer Institute. Pan Cytokeratin Staining Method. NCI Thesaurus. Code

C122857.

An immunohistochemical technique used to detect the presence of a broad spectrum of acidic and basic cytokeratin proteins in a tissue sample. 